\title{
Changes in Land Use and their Effects on Soil Properties in Huixian Karst Wetland System
}

\author{
Zhongyi Li ${ }^{1}$, Zhenjiang Jin ${ }^{2,3}$, Qiang Li ${ }^{3 *}$ \\ 'Agricultural Resource and Environment Research Institute, Guangxi Academy of Agricultural Sciences, \\ Nanning 530007, China \\ ${ }^{2}$ Environmental Science and Engineering College, Guilin University of Technology, \\ Guilin 541004, China \\ ${ }^{3}$ Key Laboratory of Karst Dynamics, MLR \& Guangxi, Institute of Karst Geology, CAGS, \\ Guilin 541004, China
}

Received: 21 July 2016

Accepted: 26 September 2016

\begin{abstract}
To gain a better understanding of the impact from the land-use change in the Huixian karst wetland system, we analyzed soil microflora, enzyme activities, and physicochemical properties from three land-use types (natural wetland, paddy field, and dry farmland). The results showed that soil $\mathrm{pH}$, soil organic carbon, total nitrogen, cation exchange capacity, exchangeable $\mathrm{Ca}$ and $\mathrm{Mg}$, and the cellulase and alkaline phosphatase activities in the dry farmland were significantly lower than those in the paddy field and natural wetland $(p<0.05)$. However, soil $\mathrm{pH}$, soil organic carbon, total nitrogen, cation exchange capacity, exchangeable Ca and $\mathrm{Mg}$, and the cellulase and alkaline phosphatase activities made no significant difference to the paddy field and the natural wetland $(p>0.05)$. Moreover, the soil microbial biomass carbon and nitrogen in the dry farmland were also lower than those in the paddy field and natural wetland, although no significant differences were observed $(p>0.05)$. This suggests that, in the alkali condition, natural wetland with high biomass and weak microbial activity may be an important carbon sink. In the CCA biplot, it can be seen that the natural wetland cluster intersects with the paddy field cluster and the dry farmland cluster in the same quadrant (although the paddy field and the dry farmland clusters are separate). Therefore, we concluded that the natural wetland usually was reclaimed as paddy field or dry farmland directly for agricultural output in the Huixian karst wetland system. The paddy field has a waterlogged condition and shows the similar results to natural wetland, which can be regarded as artificial wetland. In view of the similar ecosystem services by paddy fields as substitutes of natural wetland, if the degradation trend of natural karst wetland can't be reversed, the paddy field should be preserved in the Huixian karst wetland system for its ecosystem service.
\end{abstract}

Keywords: alkali condition, carbon sink, artificial wetland, ecosystem service

*e-mail: glqiangli@hotmail.com 


\section{Introduction}

A wetland has important functions and values in the reduction of flooding and maintaining carbon storage [1]. However, due to anthropogenic factors, some wetlands have been reclaimed as agricultural or urban fields [1].

Wetland conversion involves soil changes, such as soil physical change [2-4], and biogeochemical change, which include changes in decomposition rates and oxidation states and the mobility of nutrient species [5]. Moreover, the land change/conversion of natural wetland can change carbon release to the atmosphere [6-7]. Although organic materials, soil microflora, and enzyme activities are important components of the soil matrix and their transformation plays a significant role in soil fertility and biogeochemical cycles from the local to the global level, little is known about the changes in land use and their effects on soil properties in the karst wetland system [5]. The reason is that their inner relationship relating to land change is extremely complex, especially in the aerobic/ anaerobic transient conditions. Therefore, the monitoring and analysis of wetland conversion usually was based on remotely sensed images [8]. To gain insights into the land change/conversion of natural wetland through analysis of soil quality, canonical correspondence analysis (CCA) plus other statistical analysis was adopted to describe their inner relationship.

Canonical correspondence analysis as a useful method can simplify large sets of environmental samples or abundance data, and identify and quantify the internal relationships of environmental factors [9-10]. Although greater data always contains some unusual samples and redundant environmental variables, their intimate relationship can be diagnosed using the CCA method [10]. Therefore, our paper aimed to provide new insights for the quantitative relationships among the soil factors at the Huixian karst wetland system relating to the conversion trend of three land-use types (natural wetland, paddy field, and dry farmland) and the influence on their ecosystem services.

\section{Materials and Methods}

\section{Study Site}

Huixian karst wetland is located at karst depressions of the town of Huixian in Lingui County, which is the largest karst wetland in China, with a mean annual temperature of $16.520 .5{ }^{\circ} \mathrm{C}$ and average annual rainfall of 1,890.4 mm (1951-2008). Since the 1950s, due to the increase of human activities and the lack of effective management and protection, the natural wetland has been continuously undermined. The water area of the wetland has gradually been shrinking and its ecosystems were seriously damaged. Now, the total wetland has been dismembered as a star-studded pond with an area of no more than $1 \mathrm{~km}^{2}[11]$.

\section{Sample Collection}

We collected 11 soil sample plots from the Huixian karst wetland system. Four sample plots were extracted from paddy fields, four sample plots were extracted from dry farmland, and three sample plots were extracted from natural karst wetland. At each sample plot $(20 \times 20 \mathrm{~m})$, three soil cores $(5 \mathrm{~cm}$ diameter) were collected at $0-20 \mathrm{~cm}$ depths and mixed. The soil samples were packaged on ice and shipped to the laboratory overnight, where the soil samples were sieved $(2 \mathrm{~mm})$, separated from rocks and roots, homogenized, and stored at $4{ }^{\circ} \mathrm{C}$ until analysis.

\section{Soil Physicochemical Properties Analysis}

Soil samples were air-dried, sieved $(0.2 \mathrm{~mm})$, and analyzed for $\mathrm{pH}$, soil organic carbon (SOC), total nitrogen (TN), and cation exchange capacity (CEC) [10-11]. Exchangeable $\mathrm{Ca}(\mathrm{E}-\mathrm{Ca})$ and $\mathrm{Mg}(\mathrm{E}-\mathrm{Mg})$ in soil samples were extracted in $1 \mathrm{M} \mathrm{KCl}$ and determined by AASZeenit700 [12].

\section{Extraction and Enumeration of Culturable Microbes}

Bacteria, actinomycetes, and fungi were extracted from wet soil using the soil-plate method [10]. Three plates of each culture medium were inoculated per dilution [10].

\section{Soil Microbial Biomass Carbon and Nitrogen}

Soil microbial biomass carbon (SMBC) was determined by the fumigation-extraction method [13]. In brief, wet soil fumigated with ethanol-free $\mathrm{CHCl}_{3}$ and non-fumigated wet soils ( $25 \mathrm{~g}$ dry weight equivalent) were extracted with $50 \mathrm{~mL}$ of $0.5 \mathrm{~mol} \mathrm{~L}^{-1} \mathrm{~K}_{2} \mathrm{SO}_{4}$ (soil:extractant ratio $=1: 2$ ) for $30 \mathrm{~min}$ by oscillating shaking at $180 \mathrm{rpm}$, and filtered organic carbon in the extracts was determined after oxidation with $0.2 \mathrm{~mol} \mathrm{~L}^{-1} \mathrm{~K}_{2} \mathrm{Cr}_{2} \mathrm{O}_{7}$ at $180^{\circ} \mathrm{C}$ for $5 \mathrm{~min}$ [14]. The soil microbial biomass carbon was calculated as follows:

\section{$\mathrm{SMBC}=\mathrm{EC} / \mathrm{kEC}$}

...where EC is the difference between organic carbon extracted from fumigated wet soils and non-fumigated wet soils, and $\mathrm{kEC}=0.38$.

Soil microbial biomass nitrogen (SMBN) was determined by analyzing total nitrogen in the $0.5 \mathrm{~mol} \mathrm{~L}^{-1}$ $\mathrm{K}_{2} \mathrm{SO}_{4}$ extracts obtained from the wet soil fumigated with ethanol-free $\mathrm{CHCl}_{3}$ and non-fumigated wet soils $(25 \mathrm{~g}$ dry weight equivalent) [13]. $20 \mathrm{ml} \mathrm{K}_{2} \mathrm{SO}_{4}$ was transferred into digesting tubes for achieving digesting solution, and $5 \mathrm{ml}$ digesting solution (sulfuric acid-mercuric sulfate potassium sulfate solution) was added to each tube. The mixture in the tubes was digested on a hot block at $160^{\circ} \mathrm{C}$ for $1 \mathrm{~h}$ and then $380^{\circ} \mathrm{C}$ for $2.5 \mathrm{~h}$. After cooling, the sample was diluted to $25 \mathrm{ml}$ with ammonia-free water and the 
concentration of $\mathrm{NH}_{4}^{+}-\mathrm{N}$ in the digester was determined using a discrete auto-analyzer. The soil microbial biomass nitrogen was calculated using the equation:

$$
\mathrm{SMBN}=\mathrm{EN} / \mathrm{kEN}, \mathrm{EN}=\mathrm{Nf}-\mathrm{Nnf}
$$

...where $\mathrm{Nf}$ is the total nitrogen in fumigated wet soil, $\mathrm{Nnf}$ is the total nitrogen in non-fumigated wet soil, and $\mathrm{kEN}=0.54$.

\section{Soil Enzyme Assays}

All enzyme activities were determined from wet samples in triplicate [10]. The cellulase activity was expressed on a soil dry weight as $\mathrm{mg}$ glucose released $\mathrm{g}^{-1} \mathrm{~h}^{-1}$. The urease activity was determined using urea as substrate, and the soil mixture was incubated at $37^{\circ} \mathrm{C}$ for $24 \mathrm{~h}$. The produced $\mathrm{NH}_{4}^{+}-\mathrm{N}$ was determined by a colorimetric method, and urease activity was expressed on a soil dry weight as $\mathrm{mg} \mathrm{NH}_{4}^{+}-\mathrm{N} \mathrm{g}^{-1} \mathrm{~h}^{-1}$. The alkaline phosphatase (APA) activity was expressed on a soil dry weight basis by correcting for water content in the soil at the time the sample was removed from the incubation bottle and is given in units of $\mathrm{mg}$ p-nitrophenol-produced $\mathrm{g}^{-1}$ soil $\mathrm{h}^{-1}$.

\section{Data Analysis}

The descriptive statistical analysis in mean and correlation analysis was performed using SPSS 13.0 software for Windows XP. Correlation analysis with the source data was done using the Pearson correlation method with significance defined at $\mathrm{p}<0.05$ [10-11].

The significance of differences among means in the same column was calculated using JMP version 5.0, SAS Institute Inc., Cary, NC, USA. Different letters in the same column indicate significant differences in activity at $\mathrm{p}<0.05$ [10-11].

The CANOCO for Windows 4.5 program was used to compute CCA for explaining the contribution of each influencing factor [10]. Moreover, Pearson correlation analysis and CCA can prove each other [10].

\section{Results and Discussion}

\section{Soil Physicochemical Character}

Table 1 shows soil physicochemical properties. Soil pH, SOC, TN, and CEC in the dry farmland were significantly lower than those in the paddy field and natural wetland $(p<0.05)$, though the above results have no significant difference in the paddy field and the natural wetland.

A wetland is a land area saturated with water, either permanently or seasonally [1]. Although wetlands occupy only $4-6 \%$ of the earth's land area ( $\sim 530-570 \mathrm{mha})$, they store a substantial amount of carbon [15]. Yu et al. reported that the highest mean SOC density (209.9 t
$\mathrm{C} \mathrm{ha}^{-1}$ ) was recorded from a wetland ecosystem and the lowest $\left(29.0 \mathrm{t} \mathrm{C} \mathrm{ha}^{-1}\right)$ from a desert ecosystem in China [16]. Due to the greatly reduced supply of $\mathrm{O}_{2}$ to soil and the decreased organic carbon mineralization rates in the natural wetland, the natural wetland shows a high content of soil organic carbon in the anaerobic environment [17]. In the anaerobic environment, anaerobic microorganisms as well as photosynthesis by submerged macrophytes can create high $\mathrm{pH}$ values in the aquatic environment [18]. Moreover, the study site is located at the karst area with calcium-rich and high alkaline character. So the $\mathrm{pH}$ value in the natural wetland is higher than that in the dry farmland.

In the waterlogged condition, increased water residence times in wetlands are due, in part, to the dense stands of aquatic plants that characterize these ecosystems [15, 19]. Aquatic plants increase nitrogen retention through vegetative uptake and provide favorable conditions for sedimentation and denitrification [19]. In our study, the natural wetland retains the highest proportion of total nitrogen loading (Table 1) and the importance of water residence time to nitrogen retention was supported by Jacobs and Harrison [19].

CEC is calculated as the sum of exchangeable cations ( $\mathrm{Ca}, \mathrm{Mg}, \mathrm{K}, \mathrm{Na}, \mathrm{Al}, \mathrm{Fe}$, and $\mathrm{Mn}$ ), which drives nitrification and oxygen transfer in flood and drains wetland treatment systems [20]. Ammonium cations are adsorbed to negatively charge surfaces when wetland cells are flooded. Babadi et al. reported that adsorption of nitrogen products is known to be stronger on soils with high cation-exchange capacity [21]. Moreover, accumulated organic materials in wetland form humic substances that have significant CEC [22]. So, in the natural wetland, CEC is greater than that in the dry farmland. In the wetland of Brazilian Pantanal, surface $(0-10 \mathrm{~cm})$ soil also had significantly higher soil organic matter and cation exchange capacity [23]. Moreover, greater content of exchangeable $\mathrm{Ca}$ or $\mathrm{Mg}$ was relating to higher cation exchange capacity as observed in the natural wetland (Table 1).

As for the paddy field, it also has a waterlogged condition that is similar to the wetland in many ways and is regarded as an artificial wetland [24]. Then it was found that soil $\mathrm{pH}, \mathrm{SOC}, \mathrm{TN}, \mathrm{CEC}$, and exchangeable $\mathrm{Ca}$ and $\mathrm{Mg}$ in the paddy field were similar to those in the natural wetland, which are higher than those in the dry farmland $(\mathrm{p}>0.05)$.

\section{Soil Microbial Population and Biomass}

Table 2 lists soil microbial population and biomass. The microbial category in the natural wetland, paddy field, and dry farmland was performed in the order of bacteria $>$ actinomycetes $>$ fungi. The bacteria number was $0.61 \times 10^{7} \sim 4.36 \times 10^{7} \mathrm{cfu} \mathrm{g}^{-1}$, with the highest proportion of $67.30 \sim 95.61 \%$ in the total soil microbial population; followed by actinomycetes, whose number and proportion were $1.44 \times 10^{6} \sim 2.65 \times 10^{6} \mathrm{cfu}^{-1}$ and $5.81 \sim 18.95 \%$, respectively. However, the fungi number was 
Table 1. Soil physicochemical properties in karst wetland system (mean values).

\begin{tabular}{|c|c|c|c|c|c|c|}
\hline Land-use type & $\mathrm{pH}$ & $\begin{array}{c}\mathrm{SOC} \\
\left(\mathrm{g} \mathrm{kg}^{-1}\right)\end{array}$ & $\begin{array}{c}\mathrm{TN} \\
\left(\mathrm{g} \mathrm{kg}^{-1}\right)\end{array}$ & $\begin{array}{c}\mathrm{CEC} \\
\left(\mathrm{mol} \mathrm{kg}^{-1}\right)\end{array}$ & $\begin{array}{c}\text { Exchangeable Ca } \\
\left(\mathrm{mol} \mathrm{kg}^{-1}\right)\end{array}$ & $\begin{array}{c}\text { Exchangeable Mg } \\
\left(\mathrm{mol} \mathrm{kg}^{-1}\right)\end{array}$ \\
\hline Paddy field & $7.91 \mathrm{a}$ & $22.33 \mathrm{a}$ & $2.33 \mathrm{a}$ & $24.09 \mathrm{a}$ & $1.22 \mathrm{ab}$ & $1.23 \mathrm{ab}$ \\
\hline Natural wetland & $7.87 \mathrm{a}$ & $21.77 \mathrm{a}$ & $2.28 \mathrm{a}$ & $19.46 \mathrm{a}$ & $1.44 \mathrm{a}$ & $1.34 \mathrm{a}$ \\
\hline Dry farmland & $6.64 \mathrm{~b}$ & $12.78 \mathrm{~b}$ & $1.38 \mathrm{~b}$ & $9.56 \mathrm{~b}$ & $1.01 \mathrm{~b}$ & $0.99 \mathrm{~b}$ \\
\hline
\end{tabular}

Notes: Different letters in the same column are significantly different at the 0.05 probability level.

$2.92 \times 10^{4} \sim 6.52 \times 10^{4} \mathrm{cfu} \mathrm{g}^{-1}$ and the proportion was less than $1 \%$, just only $0.14 \sim 0.38 \%$. However, the numbers of living bacteria, actinomycetes, and fungi in the natural wetland are lower than those in the paddy field and dry farmland. The reason is that the microbial population was counted with the aerobic plate count method using a serial dilution [10]. The microorganisms from the natural wetland are adapted to anaerobic soils. Under aerobic stress, the growth and activity of anaerobic microbial communities will be inhibited. So the soil microbial population from the natural wetland sample only reflects the aerobic microbial communities and the anaerobic microbial communities were ignored. The paddy field has high microbial communities as a consequence of drought and flooding conversion from aerobic to anaerobic conditions [25-26]. The frequent changes of hydrological conditions lead to continuous stress for microorganisms in soil and thus to increased microbial populations from the paddy field using the plate count method. So the soil microbial population in the paddy field is significantly higher than that in the dry farmland $(\mathrm{p}<0.05)$.

Soil microbial biomass is closely related to soil microbial population. Mitsch et al. pointed out that natural wetlands, which are primary carbon sinks, are usually characterized by high biomass, low temperature, high humidity, weak microbial activity, and hence a low carbon dioxide release rate [15]. In our study, SMBC and SMBN in the natural wetland were higher than those in the dry farmland. Due to the paddy field with many characteristics similar to the natural wetland, the values of SMBC and SMBN in the paddy field approximated to those in the natural wetland.

\section{Soil Enzymatic Activities}

Soil enzymes play an essential role in catalyzing reactions necessary for organic matter decomposition and nutrient cycling in ecosystems [27]. Cellulase catalyzes an endohydrolysis of 1, 4-ß-D glucosidic linkages in cellulose. In our study, cellulase activity in the natural wetland and paddy field is significantly higher than that in dry farmland. Liu and Toyohara suggested that low cellulose activity in soil could be ascribed to a low level of cellulase supplied by microorganisms [28]. In the dry farmland, farmers were accustomed to removing the aboveground parts of plants, so the limited supply of plant organic matter in the soil as the enzyme substrate will retard the cellulase activity (Table 3 ). Alkaline phosphatase could catalyze the conversion of organic phosphorus to an inorganic one and is involved in P nutrient cycling [29]. Xia et al. proposed that extracellular phosphatase activity was high in the streambed sediments, which probably contributed significantly to the flux of phosphorus in sediment by hydrolyzing phosphomonoesters, making free phosphate available to the sediment microorganisms [30]. Hence, the alkaline phosphatase activity in the natural wetland and paddy field is significantly higher than that in dry farmland (Table 3). Urease is the enzyme responsible for the hydrolysis of urea to $\mathrm{NH}_{3}$, which can be assimilated by microbes and plants. The rate of urea hydrolysis depends on several factors such as soil type, organic matter content, soil moisture content, $\mathrm{CaCO}_{3}$ content, temperature, level of salinity, and alkalinity. Some of these factors accelerate and others retard the rate of urea hydrolysis in soils [31]. Reports of the influences of some soil properties on soil urease activities are inconsistent [32]. In our study, the urease activities have no notable variety with land-use change (Table 3).

\section{Statistical and Canonical Correspondence Analysis}

Canonical correspondence analysis and Pearson correlation analysis were used to explore the relationships

Table 2. Soil microbial population, biomass, and quotients in karst wetland system (mean values).

\begin{tabular}{|c|c|c|c|c|c|c|}
\hline Land-use type & $\begin{array}{c}\text { Bacteria } \\
\left.\left(\times 10^{7} \mathrm{CFU} \mathrm{g}\right)^{-1}\right)\end{array}$ & $\begin{array}{c}\text { Fungi } \\
\left.\left(\times 10^{4} \mathrm{CFU} \mathrm{g}\right)^{-1}\right)\end{array}$ & $\begin{array}{c}\text { Actinomycete } \\
\left.\left(\times 10^{6} \mathrm{CFU} \mathrm{g}\right)^{-1}\right)\end{array}$ & $\begin{array}{c}\text { Total microbial population } \\
\left(\times 10^{7} \mathrm{CFU} \mathrm{g}^{-1}\right)\end{array}$ & $\begin{array}{c}\text { SMBC } \\
\left(\mathrm{mg} \mathrm{kg}^{-1}\right)\end{array}$ & $\begin{array}{c}\text { SMBN } \\
\left(\mathrm{mg} \mathrm{kg}^{-1}\right)\end{array}$ \\
\hline Paddy field & $4.36 \mathrm{a}$ & $6.41 \mathrm{a}$ & $2.65 \mathrm{a}$ & $4.56 \mathrm{a}$ & $267.07 \mathrm{a}$ & $21.26 \mathrm{a}$ \\
\hline Natural wetland & $0.61 \mathrm{~b}$ & $2.92 \mathrm{~b}$ & $1.44 \mathrm{~b}$ & $0.76 \mathrm{~b}$ & $273.80 \mathrm{a}$ & $20.96 \mathrm{a}$ \\
\hline Dry farmland & $1.42 \mathrm{~b}$ & $6.52 \mathrm{a}$ & $1.93 \mathrm{ab}$ & $2.11 \mathrm{~b}$ & $159.13 \mathrm{a}$ & $16.00 \mathrm{a}$ \\
\hline
\end{tabular}

Notes: Different letters in the same column are significantly different at the 0.05 probability level. 
Table 3. Soil enzyme activities in the Huixian karst wetland system (mean values).

\begin{tabular}{|c|c|c|c|}
\hline Land-use type & $\begin{array}{c}\text { Cellulase } \\
\left(\mathrm{mg} \mathrm{g}^{-1} \mathrm{~h}^{-1}\right)\end{array}$ & $\begin{array}{c}\text { Urease } \\
\left(\mathrm{mg} \mathrm{g}^{-1} \mathrm{~h}^{-1}\right)\end{array}$ & $\begin{array}{c}\text { APA } \\
\left(\mathrm{mg} \mathrm{g}^{-1} \mathrm{~h}^{-1}\right)\end{array}$ \\
\hline Paddy field & $66.87 \mathrm{a}$ & $1.57 \mathrm{a}$ & $1.61 \mathrm{ab}$ \\
\hline Natural wetland & $51.56 \mathrm{ab}$ & $1.35 \mathrm{a}$ & $2.07 \mathrm{a}$ \\
\hline Dry farmland & $38.57 \mathrm{~b}$ & $1.71 \mathrm{a}$ & $0.88 \mathrm{~b}$ \\
\hline
\end{tabular}

Notes: Different letters in the same column are significantly different at the 0.05 probability level.

between soil physicochemical properties, soil microflora, and enzyme activities in the karst wetland systems (Fig. 1 and Table 4). From Fig. 1, it can be seen that the CCA biplot is divided into four quadrants. The soil physicochemical properties are clustered near the center of the CCA biplot. The soil microflora and enzyme activity features appear in the left quadrant and the upper right quadrant of the CCA biplot, respectively. The relative importance of soil microflora and enzyme activity features also differed in three land-use types on the CCA biplot and was clustered on the third quadrant. Natural wetland dominates the third quadrant, the paddy field dominates the second quadrant, and dry farmland dominates the right quadrant, which suggests that the natural wetland was degraded and reclaimed as paddy field or dry farmland directly. In other words, the land-use change history did not follow the sequence: natural wetland $\rightarrow$ paddy field $\rightarrow$ dry farmland. Moreover, the conclusion was also proved by local farmers.

The bacteria population and the total soil microorganisms in topsoil had the significant positive correlation coefficient $(r=0.999, p<0.01)$. From the CCA results, it will be found that the angle of vectors between bacteria and total soil microorganisms has a small corner dimension. The results indicate that bacteria are the dominant population in topsoil.

In knowledge of wetland hydrology, soil pH is the key component required to understand the capacity of wetlands to function [18]. According to Table 4, the results show the significantly positive correlation between soil $\mathrm{pH}$ and soil organic carbon, $\mathrm{TN}$, extractable $\mathrm{Ca}$, extractable $\mathrm{Mg}$, cellulose activity, APA activity, and SMBC $(r=0.961$, $0.922,0.644,0.738,0.641,0.730$, and 0.686 , respectively), and the significant negative correlation between soil $\mathrm{pH}$ and actinomyces activity $(\mathrm{r}=-0.673)$. Hence, $\mathrm{pH}$ rise might be a key factor controlling soil property in the anaerobic experiment. Zhang et al. reported that Huixian karst wetland lake is an $\mathrm{HCO}_{3}-\mathrm{Ca}-\mathrm{Mg}$ type, which was based on in-situ titrating and laboratory analysis [33]. So, under the hydrochemical effect from Huixian karst wetland lake, soil $\mathrm{pH}$ has a positive tie with the soil-extractable $\mathrm{Ca}$ and $\mathrm{Mg}$ and their relationship also is reflected on the CCA biplot when their triangular symbols have the adjacent position.

In the alkali condition, the complex compound of $\mathrm{Ca}-\mathrm{SOM}$ (soil organic matter) and $\mathrm{Mg}-\mathrm{SOM}$ will be formed. Nitrogen mineralization is the important process transferred from organic nitrogen to plant-available inorganic forms by soil microorganism. Such a positive relationship between TN and SOC content appeared due to the greater stabilization of humic molecules [34]. Moreover, elevated soil $\mathrm{pH}$ can impede soil nitrogen mineralization in a strong alkaline environment [35]. Liu et al. pointed out that the stocks of soil organic carbon in the karst area are higher than those in the no-karst area, and karst ecosystems in southwestern China may play active roles in mitigating the increasing $\mathrm{CO}_{2}$ concentration in the atmosphere [36]. Then, soil $\mathrm{pH}^{2}$ has the significantly positive correlation with SOC and $\mathrm{SMBC}$, and SOC and SMBC also have the significantly positive correlation with extractable $\mathrm{Ca}$ and extractable Mg. Soil pH can affect microbial activity in soils. Microbial activity would be inhibited in the alkali condition [37]. Whittinghill et al. reported that microbial activity was inhibited by high $\mathrm{Ca}$ and $\mathrm{Mg}$ concentrations at alkali condition [38]. Under alkali stress, bacteria as the dominant population in topsoil can adopt the environment. When nutritional conditions are not favorable, bacterial size can be reduced and duplication time can be significantly extended in comparison to rich growth conditions, which suggest that essential cellular processes like cell division, morphogenesis, and chromosome dynamics are highly coordinated with central metabolism to ensure the production of fit progeny [39]. Therefore, in the alkali condition, the effect of $\mathrm{pH}$ on soil microorganisms is bacteria $<$ fungi $<$ actinomyces, which was reflected on the CCA biplot.

Urease is produced by soil microorganisms and released into the soil for its action. Nayak et al. reported that around $80 \%$ urease activity was extracellular and complexed by soil colloids [40]. Bowles et al. (2014) showed that urease activity decreased with increasing application of $\mathrm{NH}_{3}$ - based $\mathrm{N}$ fertilizers [41]. It was hypothesized that the addition of the end product of the enzymatic reaction $\left(\mathrm{NH}_{4}^{+}\right)$suppressed urease synthesis. From Table 4 and Fig. 1 it will be found that urease activities have a negative relationship with soil TN. Therefore, urease and TN appear in a different quadrant. Moreover, our results correspond to Saha et al. that urease activity was decreased in the alkali condition [42]. Cellulases play an important role as a group of enzymes in global recycling of the most abundant polymer and cellulose in nature. Phosphatases play a meaningful role in $\mathrm{P}$ cycling, because they provide $\mathrm{P}$ for plant uptake by releasing $\mathrm{PO}_{4}$ from immobile organic $\mathrm{P}$. The significantly greater activity of alkaline phosphatase in manure and straw residues treated soil could be attributed to enhanced microbial activity [43]. Manure into soil also resulted in changes in origin, states, and/or persistence of enzymes in soil [44]. Due to the positive relationship between $\mathrm{TN}$ and $\mathrm{SOC}$ in topsoil, our results correspond to Saha et al. that cellulose showed a strong positive correlation with alkaline phosphatase in the alkali environment [42]. 


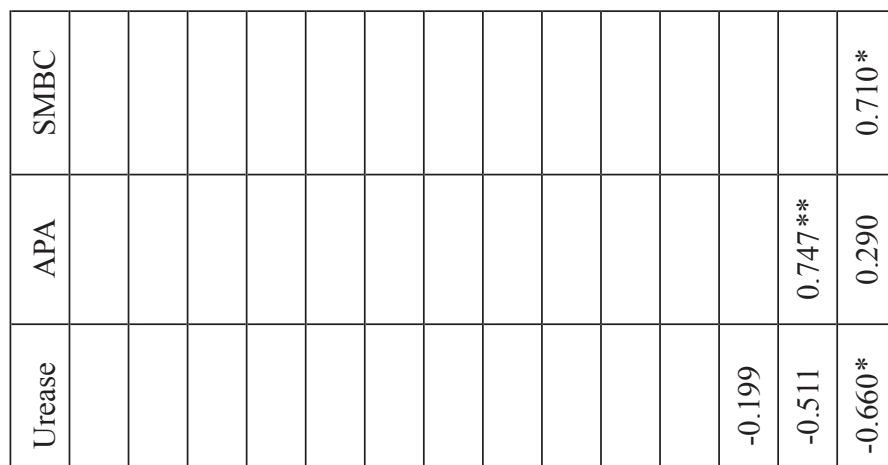

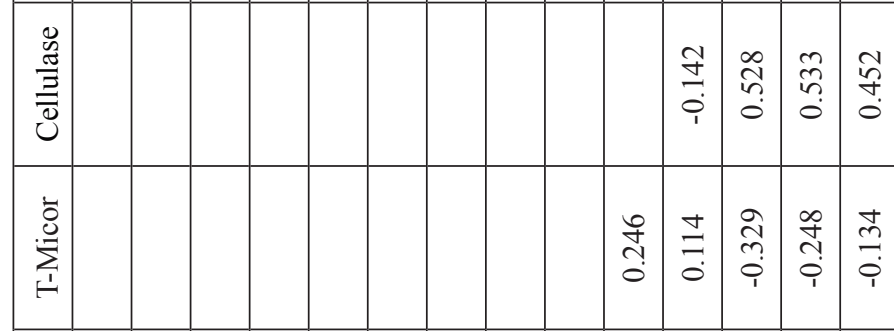

\begin{tabular}{|c|c|c|c|c|c|c|c|c|c|c|c|c|c|c|c|c|}
\hline 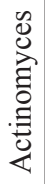 & & & & & & & & & & 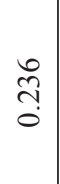 & $\begin{array}{c}1 \\
\vdots \\
0 \\
i\end{array}$ & 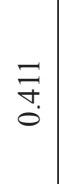 & 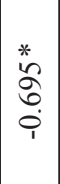 & 草 & $\begin{array}{l}\vec{\Im} \\
\stackrel{+}{i}\end{array}$ & \\
\hline $\begin{array}{l}\text { 它 } \\
\text { 吾 }\end{array}$ & & & & & & & & & $\begin{array}{c}* \\
\stackrel{*}{*} \\
\stackrel{*}{0} \\
0\end{array}$ & $\stackrel{\vec{F}}{\vec{\sigma}}$ & $\begin{array}{l}\overrightarrow{1} \\
\stackrel{0}{0}\end{array}$ & 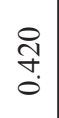 & $\begin{array}{l}\frac{1}{f} \\
\dot{T} \\
\dot{1}\end{array}$ & $\begin{array}{l}\frac{1}{f} \\
\stackrel{f}{0}\end{array}$ & $\begin{array}{l}\text { ô } \\
\text { ஸे. }\end{array}$ & \\
\hline 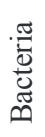 & & & & & & & & $\begin{array}{c}\sigma \\
\sigma \\
\sigma \\
\sigma\end{array}$ & $\begin{array}{l}\overrightarrow{\stackrel{े}{े}} \\
\text { }\end{array}$ & 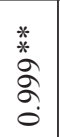 & 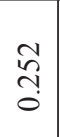 & $\begin{array}{l}8 \\
0 \\
0\end{array}$ & $\begin{array}{l}0 \\
0 \\
0 \\
0 \\
1\end{array}$ & $\begin{array}{l}\text { त̃ } \\
\text { î }\end{array}$ & $\begin{array}{l}\stackrel{े}{\rightleftharpoons} \\
\stackrel{0}{i}\end{array}$ & \\
\hline 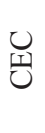 & & & & & & & & $\begin{array}{l}\infty \\
\vdots \\
\\
\\
\\
\end{array}$ & $\begin{array}{l}\infty \\
\stackrel{0}{0} \\
\\
\end{array}$ & $\stackrel{\stackrel{*}{\sim}}{\stackrel{0}{0}}$ & $\mid \begin{array}{l}\infty \\
0 \\
\tilde{o} \\
0\end{array}$ & $\mid \begin{array}{l}n \\
0 \\
0 \\
1\end{array}$ & 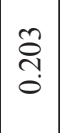 & $\stackrel{a}{\circ}$ & $\begin{array}{l}\vec{\delta} \\
\stackrel{0}{i}\end{array}$ & \\
\hline$\sum_{i=1}^{\infty}$ & & & & & $\lesssim$ & & & : & 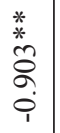 & $\begin{array}{l}0 \\
0 \\
0 \\
i \\
1\end{array}$ & ڤิ & $\begin{array}{c}\hat{D} \\
0 \\
i \\
i\end{array}$ & 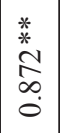 & $\begin{array}{l}* \\
* \\
\cdots \\
\tilde{w} \\
0 \\
0\end{array}$ & 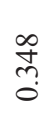 & \\
\hline ్ְ & & & & & ż & & & $\begin{array}{l}0 \\
0 \\
0 \\
0 \\
0 \\
\\
\end{array}$ & $\begin{array}{l}* \\
* \\
* \\
0 \\
0 \\
i \\
i\end{array}$ & \begin{tabular}{l} 
ते \\
?े \\
\multirow{1}{*}{}
\end{tabular} & $\begin{array}{l}0 \\
m \\
0 \\
0\end{array}$ & $\mid \begin{array}{l}n \\
n \\
n \\
1 \\
1\end{array}$ & 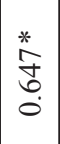 & \begin{tabular}{l}
$*$ \\
\multirow{2}{*}{} \\
$\stackrel{2}{\sigma}$ \\
0
\end{tabular} & 菾 & \\
\hline Z & & & \begin{tabular}{l}
$*$ \\
\multirow{2}{*}{} \\
2 \\
$\vdots$ \\
0
\end{tabular} & 莡 & 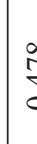 & & & $\begin{array}{l}\text { के } \\
\\
\end{array}$ & \begin{tabular}{l}
$*$ \\
\multirow{2}{*}{} \\
$\stackrel{0}{0}$ \\
$\stackrel{i}{i}$
\end{tabular} & 节 & $\begin{array}{l}\frac{*}{\sigma} \\
\stackrel{6}{0} \\
0\end{array}$ & 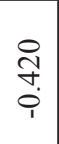 & $\mid \begin{array}{c}* \\
* \\
\infty \\
0 \\
0 \\
0 \\
\end{array}$ & $\begin{array}{l}* \\
* \\
i n \\
\hat{n} \\
0\end{array}$ & $\begin{array}{l}+ \\
\infty \\
\stackrel{n}{0}\end{array}$ & 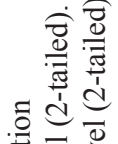 \\
\hline O্ & & \begin{tabular}{l}
$*$ \\
\multirow{*}{*}{} \\
$\stackrel{\alpha}{\alpha}$ \\
$\vdots$ \\
0
\end{tabular} & $\begin{array}{l}* \\
0 \\
0 \\
0 \\
0 \\
0\end{array}$ & $\begin{array}{l}* \\
\stackrel{*}{0} \\
0\end{array}$ & 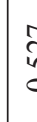 & & & 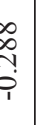 & $\begin{array}{l}* \\
\infty \\
0 \\
0 \\
0 \\
1\end{array}$ & $\frac{\circ}{\circ}$ & \begin{tabular}{l}
$*$ \\
\multirow{0}{*}{} \\
0 \\
0 \\
0
\end{tabular} & $\begin{array}{l}0 \\
0 \\
m \\
\hat{i} \\
1\end{array}$ & $\begin{array}{l}* \\
\hat{2} \\
6 \\
0 \\
0\end{array}$ & \begin{tabular}{l}
$*$ \\
\multirow{3}{*}{} \\
0 \\
0 \\
0
\end{tabular} & $\begin{array}{l}0 \\
0 \\
\vdots \\
0\end{array}$ & 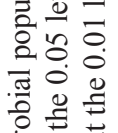 \\
\hline$\stackrel{T}{2}$ & 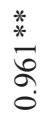 & 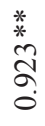 & 苦 & $\begin{array}{l}* \\
* \\
0 \\
0 \\
0\end{array}$ & 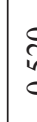 & & & $\begin{array}{l}\infty \\
? \\
? \\
1 \\
1\end{array}$ & 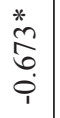 & $\stackrel{\text { nิ }}{0}$ & 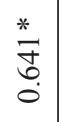 & $\begin{array}{l}n \\
\hat{n} \\
0 \\
i \\
1\end{array}$ & $\begin{array}{l}* \\
0 \\
0 \\
0 \\
0\end{array}$ & $\mid \begin{array}{l}* \\
0 \\
0 \\
0 \\
0 \\
0\end{array}$ & 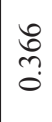 & 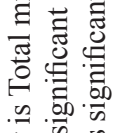 \\
\hline & రి & Z & $\underbrace{\pi}_{1}$ & $\sum_{i=1}^{\infty}$ & 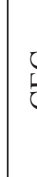 & & & 晜 & 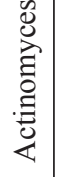 & 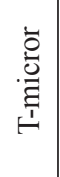 & 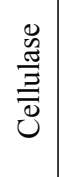 & 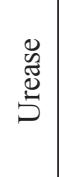 & 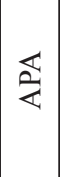 & $\sum_{i=1}^{\infty}$ & $\sum_{n=}^{Z}$ & 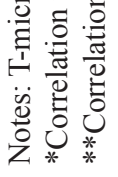 \\
\hline
\end{tabular}




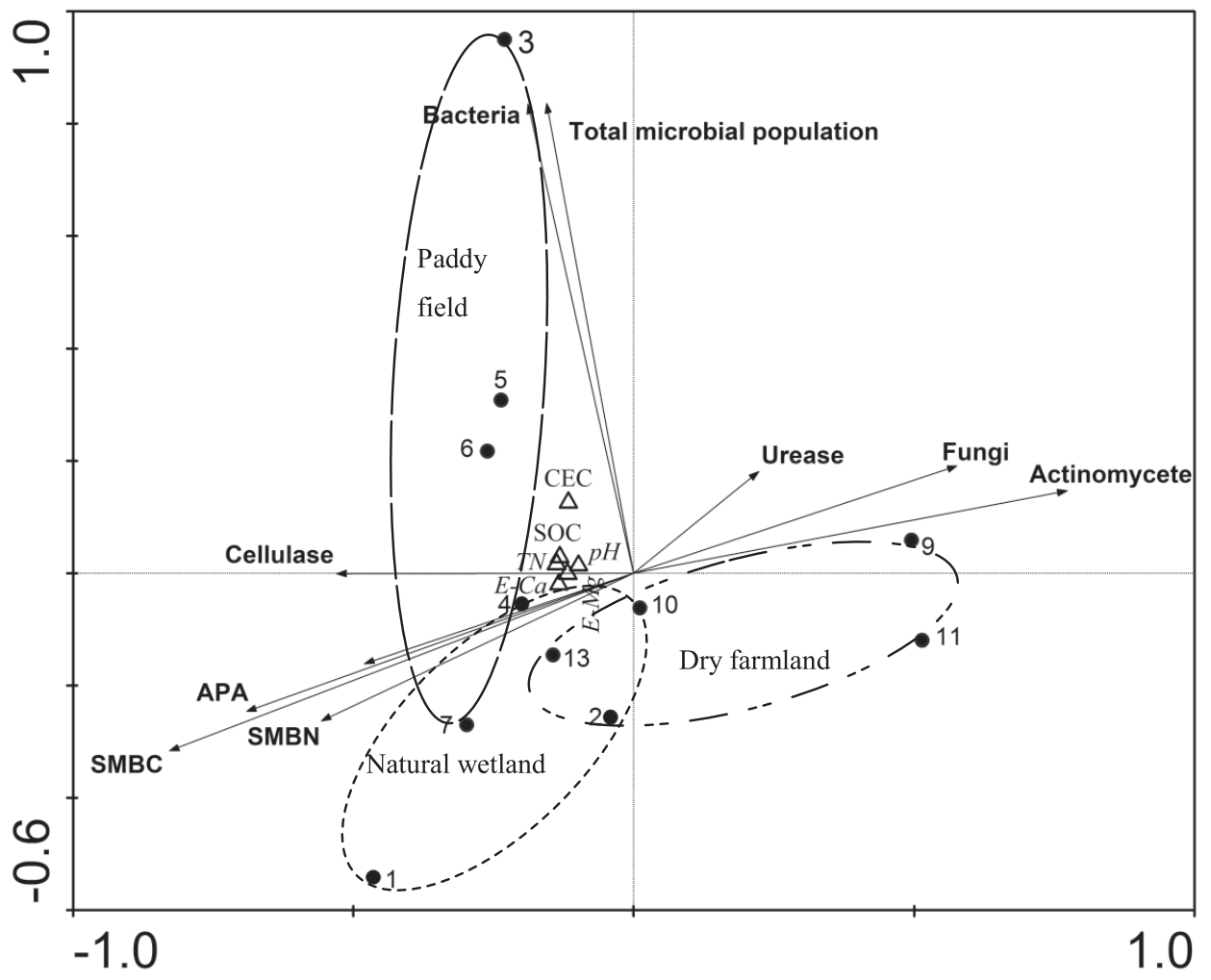

Fig. 1. CCA biplot of soil microbial features and soil physicochemical properties.

- Sample plot number

\section{Conclusions}

Wetlands play an active role in stocking soil organic carbon in a karst area. The paddy field has the similar function to natural wetland, which can be regarded as an artificial wetland class. Today, under anthropogenic impact, the natural wetland is gradually shrinking and wetland ecosystems have been damaged due to agricultural management. According to our results, the land degradation pattern was traced from natural wetland to paddy field or dry farmland directly in the Huixian karst wetland system. If a paddy field or dry farmland cannot be reversed to natural wetland due to human activities, effective management and protection in the Huixian karst wetland system is to maintain the paddy field as a substitute for natural wetland due to its similar ecosystem services, which can keep the greater stabilization of humic molecules in the alkali environment.

\section{Acknowledgements}

This work was supported by the key project of the Ministry of Science and Technology of China (No. 2016YFC0502500/2016YFC0502501), the National Science Foundation of China (Nos. 41641026 and 41361054), the National Science Foundation of Guangxi Province (Nos. 2015GXNSFGA139010, 2014GXNSFCA118012, 2011GXNSFD018002,
2011GXNSFA018006, and 2010GXNSFB013004), the Guangxi S\&T Program (Nos. Guikehe14123001-13 and 20140122-1), and the Fundamental Research Funds for CAGS (No. YYWF201505).

\section{References}

1. DAVIDSON N.C. How much wetland has the world lost? Long-term and recent trends in global wetland area. Mar. Freshwater. Res. 65 (10), 934, 2014.

2. KOOL D.M., BUURMAN P., HOEKMAN D.H. Oxidation and compaction of a collapsed peat dome in central Kalimantan. Geoderma. 137, 217, 2006.

3. GEBHARDT S., FLEIGE H., HORN R. Shrinkage processes of a drained riparian peatland with subsidence morphology. J. Soils. Sediments. 34, 484, 2009.

4. ZIYAEE A., ROSHANI M.R. A survey study on Soil compaction problems for new methods in agriculture. Int. Res. J. Appl. Basic Sci. 3 (9), 1787, 2012.

5. LAL R. Carbon management in agricultural soils. Mitig. Adapt. Strat. Glob. Change. 12, 303, 2007.

6. CHENG W. Rhizosphere priming effect: its functional relationships with microbial turnover, evapotranspiration, and C-N budgets. Soil. Biol. Biochem. 41, 1795, 2009.

7. GARTZIA-BENGOETXEA N., GONZA'LEZ-ARIAS A., MERINO A., ARANO I.M.D. Soil organic matter in soil physical fractions in adjacent semi-natural and cultivated stands in temperate Atlantic forests. Soil. Biol. Biochem. 41, 1674,2009

8. HU G.Y., DONG Z.B., LU J.F., YAN C.Z. Driving forces of land use and land cover change (LUCC) in the Zoige 
Wetland, Qinghai-Tibetan Plateau. Sci. Cold. Arid. Reg. 4 (5), 0422, 2012.

9. LIANG J., HUA S.S., ZENG G.M., YUAN Y.J., LAI X., LI X.D., LI F., WU H.P., HUANG L., YU X. Application of weight method based on canonical correspondence analysis for assessment of Anatidae habitat suitability: A case study in East Dongting Lake, Middle China. Ecol. Eng. 77, 119, 2015.

10. JIN Z.J., LI Z.Y., LI Q., HU Q.J., YANG R.M., TANG H.F., LI G.W. Canonical correspondence analysis of soil heavy metal pollution, microflora and enzyme activities in the $\mathrm{Pb}-$ $\mathrm{Zn}$ mine tailing dam collapse area of Sidi village, SW China. Environ. Earth. Sci. 73 (1), 267, 2015.

11. JIN Z.J., CHENG Y.P., LI Q., ZENG H.H., LUO K., HUANG J.Y., LU W.T., TANG Z.Q. Content of Soil Organic Carbon and Its Relationship with Nutrients in Karst Cave Wetlands, Paddy Fields and Dry Farmlands in Huixian. Wetland. Sci. 2 (4), 485, 2014

12. COLlignON C., CALVARUSO C., TURPAUlT M.P. Temporal dynamics of exchangeable $\mathrm{K}, \mathrm{Ca}$ and $\mathrm{Mg}$ in acidic bulk soil and rhizosphere under Norway spruce (Picea abies Karst.) and beech (Fagus sylvatica L.) stands. Plant. Soil. 349 (1-2), 355, 2011.

13. MONDINI C., CAYUELA M.L., SANCHEZ-MONEDERO M.A., ROIG A., BROOKES P.C. Soil microbial biomass activation by trace amounts of readily available substrate. Biol. Fert. Soils. 42 (6), 542, 2006.

14. BLAZEWICZ S.J., BARNARD R.L., DALY R.A., FIRESTONE M.K. Evaluating rRNA as an indicator of microbial activity in environmental communities: limitations and uses. The ISME. J. 7 (11), 2061, 2013.

15. MITSCH W.J., BERNAL B., NAHLIK A.M., MANDER Ü., ZHANG L., ANDERSON C.J., JØRGENSEN S.E., BRIX $\mathrm{H}$. Wetlands, carbon, and climate change. Landscape. Ecol. 28 (4), 583, 2013.

16. YU D.S., SHI X.Z., WANG H.J., SUN W.X., CHEN J.M., LIU Q.H., ZHAO Y.C. Regional patterns of soil organic carbon stocks in China. J. Environ. Manage. 85 (3), 680, 2007.

17. BABAUTA J.T., NGUYEN H.D., HARRINGTON T.D., RENSLOW R., BEYENAL H. pH, redox potential and local biofilm potential microenvironments within Geobacter sulfurreducens biofilms and their roles in electron transfer. Biotechnol. Bioen. 109 (10), 2651, 2012.

18. REZANEZHAD F., COUTURE R.M., KOVAC R., O'CONNELL D., VAN C.P. Water table fluctuations and soil biogeochemistry: An experimental approach using an automated soil column system. J. Hydrol. 509, 245, 2014.

19. JACOBS A.E., HARRISON J.A. Effects of floating vegetation on denitrification, nitrogen retention, and greenhouse gas production in wetland microcosms. Biogeochemistry. 119 (1-3), 51, 2014.

20. ALLEN C.R., STEIN O.R., HOOK P.B., BURR M.D., PARKER A.E., HAFLA E.C. Temperature, plant species and residence time effects on nitrogen removal in model treatment wetlands. Water. Sci. Technol. 68 (11), 2337, 2013.

21. BABADI F.E., YUNUS R., RASHID S.A., SALLEH M.A.M., ALI S. New coating formulation for the slow release of urea using a mixture of gypsum and dolomitic limestone. Particuology. 2015. doi:10.1016/j.partic.2014.12.011

22. GRUBA P., MULDER J. Tree species affect cation exchange capacity (CEC) and cation binding properties of organic matter in acid forest soils. Sci. Total. Environ. 511, 655, 2015.

23. VOURLITIS G.L., LOBO F.D.A., BIUDES M.S., RODRÍGUEZ O.C.E., NOGUEIRA J.D.S. Spatial variations in soil chemistry and organic matter content across an invasion front in the Brazilian Pantanal. Soil. Sc. Soc. Am. J. 75 (4), 1554, 2011.

24. NATUHARA Y. Ecosystem services by paddy fields as substitutes of natural wetlands in Japan. Ecol. Eng. 56, 97, 2013.

25. LEWIS D.B., FEIT S.J. Connecting carbon and nitrogen storage in rural wetland soil to groundwater abstraction for urban water supply. Global. Change. Bio. 21 (4), 1704, 2015.

26. PERALTA A.L., LUDMER S., KENT A.D. Hydrologic history influences microbial community composition and nitrogen cycling under experimental drying/wetting treatments. Soil. Biol. Biochem. 66, 29, 2013.

27. YANG J., HUANG J.H., LAZZARO A., TANG Y., ZEYER J. Response of soil enzyme activity and microbial community in vanadium-loaded soil. Water. Air. Soil. Poll. 225 (7), 1, 2014.

28. LIU W., TOYOHARA H. Sediment-complex-binding cellulose breakdown in wetlands of rivers. Fisheries. Sci. 78 (3), 661, 2012.

29. GOLL D.S., BROVKIN V., PARIDA B.R., REICK C.H., KATTGE J., REICH P.B., NIINEMETS Ü. Nutrient limitation reduces land carbon uptake in simulations with a model of combined carbon, nitrogen and phosphorus cycling. Biogeosciences. 9, 3547, 2012.

30. XIA Z.Y., ZHOU Y.Y., CHEN F., SONG C.L., LI J.Q. Stratification of alkaline phosphatase in sediments of two urban lakes and its effect on phosphorus cycle. Acta. Ecol. Sin. 32 (3), 138, 2012.

31. CALVO P., WATTS D.B., AMES R.N., KLOEPPER J.T.H.A. Microbial-Based Inoculants Impact Nitrous Oxide Emissions from an Incubated Soil Medium Containing Urea Fertilizers. J. Environ. Qual. 42, 704, 2013.

32. VAHED H.S., SHAHINROKHSAR P., REZAEI M. Influence of Some Soil Properties and Temperature on Urease Activity in Wetland Rice Soils. American-Eurasian. J. Agric. Environ. Sci. 11 (3), 310, 2011.

33. ZHANG S., WANG L., HU J., ZHANG W., FU X., LE Y., JIN F. Organic carbon accumulation capability of two typical tidal wetland soils in Chongming Dongtan, China. J. Environ. Sci. 23 (1), 87, 2011

34. WARING B.G., AVERILL C., HAWKES C.V. Differences in fungal and bacterial physiology alter soil carbon and nitrogen cycling: insights from meta-analysis and theoretical models. Ecol. Lett. 16 (7), 887, 2013.

35. BAI J., GAO H., XIAO R., WANG J., HUANG C. A review of soil nitrogen mineralization as affected by water and salt in coastal wetlands: issues and methods. Clean-Soil. Air. Water. 40 (10), 1099, 2012.

36. LIU Y., LIU C., WANG S., GUO K., YANG J., ZHANG X., LI G. Organic carbon storage in four ecosystem types in the karst region of southwestern China. Plos. One. 8 (2), e56443, 2013.

37. YU J., DONG H., LI Y., WU H., GUAN B., GAO Y., WANG Y. Spatiotemporal Distribution Characteristics of Soil Organic Carbon in Newborn Coastal Wetlands of the Yellow River Delta Estuary. Clean-Soil. Air. Water. 42 (3), 311, 2014

38. WHITTINGHILL K.A., HOBBIE S.E. Effects of $\mathrm{pH}$ and calcium on soil organic matter dynamics in Alaskan tundra. Biogeochemistry. 111 (1-3), 569, 2012.

39. FOULQUIER E., DOAN T., POMPEO F., GALINIER A. Strategies to adapt cellular processes to nutrient availability in bacteria. Front. Biosci. 4, 1007, 2011.

40. NAYAK D.R., JAGADEESH B.Y., ADHYA T.K. Long-term application of compost influences microbial biomass and 
enzyme activities in a tropical Aeric Endoaquept planted to rice under flooded condition. Soil. Biol. Biochem. 39, 1897, 2007.

41. BOWLES T.M., ACOSTA-MARTÍNEZ V., CALDERÓN F., JACKSON L. Soil enzyme activities, microbial communities, and carbon and nitrogen availability in organic agroecosystems across an intensively-managed agricultural landscape. Soil. Biol. Biochem. 68, 252, 2014.

42. SAHA S., PRAKASH V., KUNDU S., KUMAR N., MINA B.L. Soil enzymatic activity as affected by long term application of farm yard manure and mineral fertilizer under a rainfed soybean-wheat system in NW Himalaya. Euro. J. Soil. Biol. 44 (3), 309, 2008.
43. MANDAL A., PATRA A.K., SINGH D., SWARUP A., EBHIN M.R. Effect of long-term application of manure and fertilizer on biological and biochemical activities in soil during crop development stages. Bioresource. Technol. 98 (18), 3585, 2007.

44. ZHAO Y., YAN Z., QIN J., XIAO Z. Effects of long-term cattle manure application on soil properties and soil heavy metals in corn seed production in Northwest China. Environ. Sci. Pollut. Res. 21 (12), 7586, 2014. 
